\title{
On the rudiments of the eye tracking glottodidactics
}

\author{
SAMBOR GRUCZA
}

Received 16.06.2020,

accepted 11.08.2020.

\begin{abstract}
The article presents briefly the main aim of eye tracking supported research carried out within the scope of what is broadly understood to be second language learning and teaching. Special emphasis is placed on the capabilities and limitations of eye tracking based cognition in second language learning and teaching. Eye tracking based research of second language learning and teaching is, from the scientific point of view, relevant in so as much as it measurably contributes to the creation of new, or the verification of previously acquired, scientific knowledge, in as much as it contributes to the scientific cognition of the object of glottodidactics. The article introduces the basic assumptions of eye tracking glottodidactics. In this sense it constitutes the first part of the presentation of the results of the eye tracking supported project "Developing language competences in secondary school students with developmental dyslexia", which was implemented at the University of Warsaw. The second part of the presentation is the article "Layout changes in the textbook of English and their influence on the dyslectic students' work effectiveness - an eye tracking analysis" written by Agnieszka Andrychowicz-Trojanowska and published in this issue of Beyond Philology.
\end{abstract}




\title{
Keywords
}

glottodidactics, eye tracking, glottodidactic methods, experimental glottodidactics

\section{O podstawach glottodydaktyki eye tracking}

\begin{abstract}
Abstrakt
Celem poniższego artykułu jest krótkie przedstawienie głównego celu glottodydaktycznie ukierunkowanych badań okulograficznych, czyli głównego celu glottodydaktyki okulograficznej. Szczególna uwage artykuł poświęca zagadnieniom dotyczacym metodologicznym ograniczeniom glottodydaktycznego poznania okulograficznego procesów uczenia się języków obcych. Badania okulograficzne dotyczące nauczania i uczenia się języków obcych są $z$ naukowego punktu widzenia istotne o tyle, o ile w wymierny sposób przyczyniaja się do tworzenia nowej lub weryfikacji wcześniej nabytej wiedzy naukowej, o ile przyczyniaja się do naukowego poznania przedmiotu glottodydaktyki. W artykule przedstawiono podstawowe założenia glottodydaktyki okulograficznej. Dlatego niniejszy tekst traktujemy jako pierwszą część prezentacji wyników projektu realizowanego na Uniwersytecie Warszawskim pt. „Rozwijanie kompetencji językowych uczniów szkół ponadgimnazjalnych $z$ dysleksja rozwojowa”. Druga częścia tej prezentacji jest artykuł pt. "Zmiany układu w podręczniku języka angielskiego i ich wpływ na efektywność pracy uczniów dyslektycznych - analiza okulograficzna" autorstwa Agnieszki Andrychowicz-Trojanowskiej, opublikowanego w tym numerze „Beyond Philology”.
\end{abstract}

\section{Słowa kluczowe}

glottodydaktyka, okulografia, eye tracking, metodologia glottodydaktyczna, glottodydaktyka eksperymentalna 


\section{Introduction}

Eye tracking glottodidactics is a relatively young subfield of glottodidactic cognition; nevertheless, it has developed a considerable record of methodological and research achievements. The established standards of conducting eye tracking experiments and interpreting the collected data samples constitute solid foundations for further scientific research.

The aim of the article is to outline the main cognitive and methodological assumptions of eye tracking glottodidactics, its research potential and limitations, as well as a general description of its possible research areas. Moreover, the article constitutes an introduction to the text written by Andrychowicz-Trojanowska "Layout changes in the textbook of English and their influence on the dyslectic students' work effectiveness - an eye tracking analysis" also published in this issue of Beyond Philology.

I will explain what an eye tracking experiment consists of (in particular when it comes to eye tracking glottodidactic cognition) in the further parts of the present text. In order to introduce the topic, I will state here only that it is based on observing and registering the eye movements of study participants while they are performing a specified task, as well as drawing conclusions based on the obtained physical data or the mental behaviour of the participants, and forming or verifying hypotheses regarding such or different behaviours of the specific groups of people.

\section{On eye tracking research}

It would be wrong to think that the interest in eye movements is a completely new phenomenon. Certainly Aristotle evinced such an interest (cf. Wade 2010). It is possible that such interest might have been expressed even earlier in history. When it comes to eye tracking, it is also not a newly-devised research area. As Płużyczka (2015) rightly remarks, the beginnings of 
systematic apparatus eye tracking research can be traced in the studies of reading processes initiated at the end of 1870 s by Louis Émile Javal (1839-1907), a French ophthalmologist, the creator and director of an ophthalmology laboratory at the Sorbonne. In his studies he used a mirror which was placed on the pages of a book read by the participant. While standing behind the participant, the experimenter tracked the reflection of the subject's eyes in the mirror.

Edmund Burke Huey (1870-1913) is considered to be the creator of the first eye tracker. In 1898 he presented the results of his studies, where he used an object similar to a contact lens with an opening for the pupil. The lens was connected to an indicator showing the eyeball movement (cf. Huey 1898). The first eye trackers were invasive devices; it was necessary, for example, to anaesthetize the study participants with cocaine. The first non-invasive eye tracker, which was also relatively precise, was constructed in 1901 by two Americans, Raymond Dodge (1871-1942) and Thomas Sparks Cline (1877-?). Their device was the first optical eye tracker. Its description and method of scientific use were presented by its designers in an article entitled "The angle velocity of eye movements" (Dodge and Cline 1901). The first photo eye tracker was presented in 1937 by Guy Thomas Buswell (1891-1994). It used a light beam reflected from the eye of the participant and recorded it on a photographic film.

Modern eye trackers are devices which use highly advanced technology. They can be subdivided into three categories: static, portable and glass-based eye trackers. All of them are video eye trackers, that is, they use a camera image of the eye to recognise the reflection of an infrared beam (sent by the eye tracker) from the surface of the eye.

Both the interest in eye tracking, and, consequently, its development are illustrated, among other indications, by the number of scientific publications. According to the data from online 
sources ${ }^{1}$ the growth of global interest in eye tracking between 1970 and 2009 was linear. In 1970-1974 approximately 310 eye tracking publications were issued, in 1985-1989 there were already 829 of them, while in 2005-2009 there were as many as 15,000 such publications. In 2010-2014 an exponential growth of eye tracking publications could be observed - approximately 210,000 publications were registered. The data for 2015-2019 indicates that the growth has levelled off - approximately 220,000 new publications appeared. ${ }^{2}$

It is beyond doubt that the strong growth of interest in eye tracking has been caused by the launch of affordable portable eye trackers and also recently eye tracking glasses. Probably, numerous eye tracking publications have also emerged due to the fact that eye tracking studies of various types can now be commissioned on the eye tracking service market. It is also possible to rent eye tracking equipment.

Systematic Polish eye tracking research has started only recently. The disciplinary diversity of the research could be well depicted, although to a limited extent, by the speeches at the Polish Eye Tracking Conference ${ }^{3}$ (cf. Grucza, Płużyczka and Soluch 2014, Hansen-Schirra and Grucza 2016). The history of systematic Polish eye tracking research within the areas of linguistics, glottodidactics and translation studies is also relatively short, with roots beginning around 2010.

One of the Polish academic centres conducting systematic eye tracking research is the Faculty of Applied Linguistics at the University of Warsaw. Here, the beginnings of interest in eye tracking research could be dated to approximately 2010. This interest has intensified due to the purchase of two eye trackers, SMI RED 500 and SMI RED 250. In 2008 the Audiovisual

1 Source: http://imotionsglobal.com/blog/exponential-growth-in-academic-eye-tracking-papers-over-the-last-40-years, cited in Płużyczka, 2015: 175.

2 An interesting insight into the research-area distribution of eye tracking publications is provided by Aryadoust and Ang 2019.

3 http:/ / etr.uw.edu.pl/polish-eye-tracking-conference. 
Translation Lab was established ${ }^{4}$. It conducts mostly eye tracking studies concerned with audiovisual translation and media accessibility. Established in 2010, the Laboratory for Experimental Eye Tracking Linguistics ${ }^{5}$ focuses mostly on glottodidactic and translation-studies research. In 2019, the European Network of Eye Tracking Research, ${ }^{6}$ also at the Faculty of Applied Linguistics, was launched. It is aimed at connecting European eye tracking research centres.

We presented the first remarks regarding the scope of the research potential of eye tracking studies in the field of linguistics as early as in 2011 in the article "Lingwistyka antropocentryczna a badania okulograficzne" [Anthropocentric Linguistics and Eye Tracking Research] (cf. Grucza 2011). In the following works, the views regarding predominantly theoretical and methodological foundations of eye tracking translation studies were expressed (Grucza 2013a, 2013b, 2014).

In the meantime, the foundations have been greatly reinforced by the studies of my colleagues: mostly by Płużyczka whose monograph has allowed her to be awarded with the first habilitation (a Polish postdoctoral degree) on the basis of eye tracking translation-studies research (cf. Płużyczka 2015), and Bonek - whose doctoral thesis was the first in Poland devoted to eye tracking translation studies (cf. Bonek 2017). In 2019 the results of the research by Castelas presented in her doctoral thesis constituted the basis for granting the next doctoral degree in this area. The next eye tracking doctoral thesis by Kudła "Ocena odbioru lokalizacji językowej gier komputerowych na podstawie danych okulograficznych" [Assessment of the Perception of Computer Games Linguistic Localization Based on Eye Tracking Data] is almost complete. Recently our latest work "Czytanie pretranslacyjne a jakość tłumaczenia a vista w świetle wyników badania okulograficznego" [Pre-translation reading

\footnotetext{
${ }^{4}$ https://avt.ils.uw.edu.pl.

5 http://www.lelo.uw.edu.pl.

6 http://etr.uw.edu.pl.
} 
and the quality of sight translation in the light of eye tracking study results] was published (cf. Grucza et al. 2019).

However, our research interests are not limited to translation studies. For some years we have been simultaneously conducting intensive research in the area of eye tracking glottodidactics. The researcher whose studies have contributed the most to the consolidation of the theoretical and methodological research in this area, is undoubtedly Andrychowicz-Trojanowska. Her 2018 monograph, "Podręczniki glottodydaktyczne. Struktura - funkcja - potencjał w świetle badań okulograficznych" [Glottodidactic textbooks. Structure - function - potential in eye tracking research] is the first monograph in the field of eye tracking glottodidactics by a Polish scientist. The sample study conducted by the author consisted of 213 students (!). I would like to explain to readers who are unfamiliar with eye tracking research that this collected eye tracking data definitely constitutes not only the largest glottodidactic eye tracking database, but also probably the largest eye tracking database in Europe in the context of one scientific research project.

In the next chapter I will endeavour to very synthetically outline the rudiments of eye tracking cognition. The fourth chapter characterises in a more detailed manner some areas where eye tracking glottodidactic research should be (and could be) conducted.

\section{On eye tracking based cognition}

Eye tracking based cognition is not an easy process for several reasons. The first is that the foundation of eye tracking research is the assumption that eye movements and mental processes are correlated, that the eye movements reflect mental processes. Poole and Ball call this assumption "eye-mind hypothesis" and describe it as follows: "Eye-mind hypothesis: The principle at the origin of most eye tracking research. Assumes that what a person is looking at indicates what they are currently thinking about or attending to. Recording eye-movements can, therefore, 
provide a dynamic trace of where a person's attention is being directed in relation to a visual display such as a system interface" (Poole and Ball 2006: 216).

In other words, this hypothesis is based on the belief that eye movements are caused by mental (cognitive) processes taking place in the brain of the research subject and that, as a consequence, the eye movements can form a basis for reconstructing these processes, i.e. formulating hypotheses concerning mental (cognitive) processes taking place in their brain. Finally, the hypothesis comes down to the statement that on the basis of analyzing eye movements it is possible to draw conclusions on the manner of the course of mental processes. Soluch and Tarnowski (2013: 90) state the following on that matter:

We believe that eye-tracking as a method can be of interest to researchers for a handful of reasons. First of all, the eye movement is probably the commonest potentially intentional human behaviour - it occurs three times per second on average. Secondly, it precisely indicates what information is being received by the subject at the given time. Thirdly, at last, control of the eye movement unquestionably constitutes a model example of cooperation between automatic and controlled mechanisms, both in the aspect of perception as well as action.

Obviously, our human intellectual cognition is also essentially based on an assumption that people, while using their cognitive properties, are able to perform some cognition. In one of my works, I have called this assumption epistemic. Accordingly, the assumption that while using an eye tracker we are able to form new knowledge on something that is not subject to direct sensory observation could be (preliminarily) called an eye tracking assumption. It should be added that the eye tracking apparatus is only a more or less ideal "extension" of our senses and that it is not an "extension" of our epistemic competences. It has been clearly emphasized by $\mathrm{Ch}$. Frith, among others, who states that brain imaging experiments distinctly show the unbridgeable gap between the objective physical matter and the subjective 
intellectual experience (2007: 27). That is certainly why, while writing on the physical tools of scientific work, F. Grucza suggests the division into "senses" and "instruments sharpening them" (F. Grucza 1983: 597). Finally, it could be stated that eye tracking is a type of an instrument which sharpens the senses.

Sandra, entering into a discussion with Croft on the possibilities of mental representations, says: "Those who propose models of mental representation (or suggest such representation) often commit a fallacy. (...) When discussing mental representations, linguists are more likely to confess a belief than to prove a point" (Sandra 1998: 361). He continues: "What can linguists learn about the human mind by studying language? Let me begin by reiterating what they cannot learn. Linguists cannot address issues pertaining to processing of linguistic material. Such issues concern the language processor rather than the language itself and hence fall outside the limits of linguistic research and within the boundaries of psycholinguistics, which makes use of chronometric techniques for studying ongoing processing. Linguists cannot make statements about the representational format of language elements in the language user's mind either". And further he adds: "In contrast, linguists are able to make some statements on what is in the mind. This especially applies to humans' mental predisposition for language, which may be identified through a careful study of what makes languages typically human (...)" (Sandra 1998: 375).

Of course, reconstruction of the competences does not constitute an easy task. Luria was right when he wrote in 1974 in the first issue of "Language and Brain": "The question of the relation of language and brain belongs to the most complex problems in science. The history of attempts to solve it has been replete with confrontations of opposite approaches, often leading to dead ends. A solution to this problem requires a radical revision of our basic concepts, which have remained unchanged for many decades" (Luria 1974: 1). And yet thirty-five years later

7 S. Grucza et al. (2017b: 50). 
G. Benedetti et al. admit that: "Despite allowing for the unprecedented visualization of brain functional activity, modern neurobiological techniques have not yet been able to provide satisfactory answers to important questions about the relationship between brain and mind" (Benedetti et al. 2009: 1).

The following difficulty of eye tracking based cognition is that it is necessary to standardize the eye tracking experiment parameters. The word "parameter" here refers to a specific property of an object, context etc. that could affect the results of an eye tracking experiment. When it comes to eye tracking glottodidactics research, the following parameters determining an eye tracking experiment can be listed:

- participants' biometric parameters (sex, age, disfunctions, e.g. visual impairment, mental disorder, etc.),

- cosmetic parameters (make up),

- space parameters (properties of the room where the experiment is conducted, e.g. its size, how bright/dark it is),

- eye tracker parameters (type and properties of the device, monitor size, sampling rate),

- object parameters (the properties of the object - text, image, film, which is utilized in the experiment),

- glottodidactic parameters (e.g. the number, kind, scope of linguistic competences, types and scopes of the acquired knowledge),

- experiment parameters (e.g. experimenter's behaviour, properties of the course of experiment, experiment time, time of day when the experiment is conducted, time dedicated for performing the task).

The difficulty of conducting eye tracking research is also connected with the choice and appropriate interpretation of oculomotor (eye movement) activity indicators. The most important indicators include:

- fixations, stabilizing the gaze, the eyeball, on a specific object; the units of fixations' measurement are: their count, millisecond, second, minute, square pixel, 
- refixations, also called revisits, new fixations on objects (words) that have already been subject to fixations; they are measured in the same units as fixations,

- saccades, quick jerky movements of the eyeball between fixations,

- scanpath, the physical movement of the eyeball, expressed as the summarized length of all saccades,

- areas of interest, more frequently referred to as AOIs, areas which are particularly important for the purpose of the experiment and determined by the experimenter. ${ }^{8}$

The named indicators are only the general indicators of oculomotor activity (more on that matter in Grucza 2013b). This is not the place to list all the individual indicators. By way of example, it could be said that within fixations alone we can distinguish time of first fixation, time of all fixations, average fixation time, AOI fixation time total, fixation count, fixation frequency, fixations per second, AOI fixation count, stimulus fixation count, AOI fixations distribution, intended fixations, unintended fixations, and fixation count prior the AOI fixation.

The aforementioned lists illustrate that an eye tracking experiment is characterized by a very high degree of complexity. It is connected with a high number of parameters which may influence the final result of the eye tracking experiment. Keeping the same parameters and their values (the parametric constant) constant for all the trials within an eye tracking study is a sine qua non for achieving a high degree of explicability of the obtained eye tracking data. ${ }^{9}$ The lists demonstrate that the analysis of the obtained eye tracking data is also distinguished by a high degree of complexity. It is obvious that the choice of the appropriate oculomotor activity indicators and their appropriate interpretation translates directly into the quality of the

8 Due to space limitations no images depicting the possibilities of visualizing the data have been provided. Interested readers should refer to the works mentioned in section 4.

${ }^{9}$ How two different screen layouts can lead to different results in an eye tracking study has been shown by Spinner, Gass and Behney (2013). 
explication of the studied state of affairs or the quality of the research hypothesis verification.

Finally, it should be stated that the detailed planning of an eye tracking experiment consists in both planning the research and experiment architecture, and foreseeing the influence of the individual experiment parameters on the result, i.e. controlling the lurking and confounding variables. In the case of the second aspect it is important to know both which areas of the experiment are fully controlled, and which areas of the experiment cannot be strictly controlled or cannot be controlled at all.

\section{On eye tracking glottodidactics}

If the notion of "eye tracking" is treated as one referring to a certain cognition method, the notion of "eye tracking glottodidactics" signifies a certain scope of cognitive glottodidactic work, where the subjects of this work use eye trackers as a certain cognitive equipment and eye tracking methods as certain means of cognition. It should be added that by means of glottodidactic eye tracking cognition we can acquire verifying knowledge, gain knowledge complementing the glottodidactic knowledge that has been already obtained, or produce completely new glottodidactic knowledge.

Due to space limitations I will not undertake to describe, or even to outline, eye tracking research methodology. I can only refer the reader to the following works: Ober et al. 2009, 2002, Ober and Ober 2002a, 2002b, Richardson and Spivey 2004, Duchowski 2017, Soluch and Tarnowski 2013, Płużyczka 2015, Holmqvist and Andersson 2017. When it comes to general remarks regarding the use of eye tracking in glottodidactic research, please refer to the following works: Conklin, PellicerSánchez and Carrol 2017, Andrychowicz-Trojanowska 2018, Godfroid 2019.

This is also no place for a broad summary of the previous results of eye tracking glottodidactics studies. I will limit myself to outlining the possible areas of glottodidactic eye tracking 
research. In my view, four main research areas can be distinguished here. When it comes to the first area, it is the scope of research cognitive work, which is aimed at describing and explicating specific fragments of the glottodidactic research object. In this area the following narrow scopes of research can be distinguished:

(1) Eye tracking measuring, assessing and modelling of:

- language proficiency/attention/comprehension in second language reading,

- second language competences/learning processes,

- second language competences/learning processes regarding special educational needs

- computer-assisted second language learning,

- usability of page layout of second language learning books,

- usability of second language learning computer programs and mobile apps,

- the impact of visual and acoustic cues on second language reading/performance.

When it comes to the second research area, this includes questions referring to a certain meta-methodological sphere (cf. Hajduk 1996), i.e. firstly, questions regarding the usefulness of eye tracking methodology in glottodidactic description and the explication of specific fragments of the glottodidactic research object, and secondly, questions regarding modifying and improving the eye tracking methodology for the use of glottodidactics. In this area, the following narrow scopes of research can be distinguished:

(2) Explorations in the usefulness of eye tracking methodology for testing and monitoring of:

- second language proficiency/attention/comprehension in second language reading,

- second language competences/learning processes,

- computer-assisted second language learning,

- usability of page layout of second language learning books, 
- usability of second language learning computer programs and mobile apps,

- the impact of visual and acoustic cues on second language reading/performance.

The third area of research also includes methodological questions, but ones of a different nature than those previously mentioned. The issue is that the results of the eye tracking analysis of eye tracking data are most often are not sufficient to draw binding descriptive and explicative conclusions regarding the studied fragment of the glottodidactic research object. Consequently, they should be juxtaposed with the results gained via statistical analysis of eye tracking data and the results of the analyses of other data, for example the results of analyzing data gained in interviews, questionnaires and/or observations. Observational data may be obtained, for example, via video recording of individual eye tracking experiment trials. The juxtapositions of various results will render possible the triangulation of the obtained data and compensate for the limitations of the eye tracking method. That is why I would define the third and fourth areas of glottodidactic eye tracking research where data triangulation and method triangulation is utilized (more on that matter cf. Denzin 2009, Denzin and Lincoln 2017) as follows:

(3) Explorations of data triangulation in eye tracking glottodidactics.

(4) Explorations of triangulation methods in eye tracking glottodidactics.

My previous remarks mostly refer to the eye tracking method of gaining glottodidactic diagnostic knowledge, i.e. knowledge regarding states of affairs which are assumed to exist. However, utilizing eye trackers for glottodidactic research cannot be limited to only gaining such knowledge. Perhaps the most important aim of glottodidactics, as it has been rightly noted by $\mathrm{F}$. Grucza, is the prognostic task, that is, striving to gain prognostic knowledge, which is the knowledge regarding states of affairs 
that are assumed to exist in the future (cf. Grucza et al. 2017a, 2017b). We should further subdivide prognostic knowledge, as F. Grucza did, into (a) knowledge regarding states of affairs which are assumed to happen as consequences of states of affairs that have been already found to exist, (b) knowledge regarding how particular states of affairs will react if they are affected in a certain manner, (c) knowledge regarding the occurrence of new states of affairs, which are assumed not to exist yet.

The fundamental task of glottodidactics is to design a curriculum for teaching a specific language as well as the tools necessary to implement the curriculum, which will allow for the most efficient internalization of language competences to the highest possible degree. Accordingly, it should be noted that eye tracking research makes fulfilling this task possible because it allows us to gain knowledge of what influence the following factors will have on the efficiency and degree of internalizing language competences: a) changes in some properties of the language teaching curriculum, b) changes in some properties of the tools necessary to implement the curriculum, c) changing the tools or introducing new tools. An example of how such prognostic glottodidactic knowledge might be obtained has been illustrated by Andrychowicz-Trojanowska (2020).

\section{Conclusions}

One important issue is the numerical data regarding eye tracking publications. Another is the legitimacy and quality of the experiments conducted. Our analysis of publications devoted to eye tracking glottodidactics shows that the strong growth of interest in eye tracking does not go hand in hand with either growth in the quality of conducted studies or with growth in the quality of their results. Many of the studies have been conducted exclusively with reference to the so-called case studies, and many of the published eye tracking result interpretations are highly speculative. Also, today some percentage of eye 
tracking publications are merely an effect of satisfying the desire to be innovative.

Many authors have forgotten that experimental research is only scientifically relevant when it indeed contributes either to forming new scientific knowledge or to verifying previously gained knowledge which contributes to the scientific cognition of the research object. Some have also forgotten that an eye tracker as a tool of scientific work cannot be ex post used as a definiens of scientific work. However, to summarise this idea, it should be clearly stated that today, in comparison with the first decade of the present century, the quality of the studies conducted has improved considerably.

\section{References}

Andrychowicz-Trojanowska, Agnieszka (2018). Podręczniki glottodydaktyczne: Struktura - funkcja - potencjał $w$ świetle badań okulograficznych. [Glottodidactic textbooks. Structure - function - potential in the eye tracking research] Warszawa: Wydawnictwo Naukowe IKSI. Available at http://sn.iksi.uw.edu.pl/wp-content/ uploads/sites/306/2018/08/SN-41-A.-Andrychowicz-Trojanow ska-Podr \%C4 \%99czniki-glottodyd aktyczne.pdf.

Andrychowicz-Trojanowska, Agnieszka (2020). "Layout changes in the textbook of English and their influence on the dyslectic students' work effectiveness - an eye tracking analysis". Beyond Philology 17/3: 77-95.

Aryadoust, Vahid, Bee Hoon Ang (2019). "Exploring the frontiers of eye tracking research in language studies: a novel co-citation scientometric review". Computer Assisted Language Learning 1-37. DOI: 10.1080/09588221.2019.1647251.

Benedetti, Giulio, Giorgio Marchetti, Alexander Andrew Fingelkurts, Andrew Alexander Fingelkurts (2009). "Mind operational semantics and brain operational architectonics: A putative correspondence". The Open Neuroimaging Jour-nal 4: 53-69. Available at https://doi: 10.2174/1874440001004020053. 
Bonek, Anna (2017). Eyetracking-Analyse computergestützten Übersetzungsprozesses [An Eye Tracking Analysis of Computer-assisted Translation Process]. Frankfurt/M.: Peter Lang Verlag.

Conklin, Kathy, Ana Pellicer-Sánchez, Gareth Carrol (2017). EyeTracking. A Guide for Applied Linguistics Research. Cambridge: Cambridge University Press.

Denzin, Norman K. (2009). The Research Act. A Theoretical Introduction to Sociological Methods. New York: Routledge.

Denzin, Norman K., Yvonna S. Lincoln (eds.) (2017). Handbook of Qualitative Research (5th ed.). Thousand Oaks: Sage.

Dodge, Raymond, Thomas Sparks Cline (1901). "The angle velocity of eye movements". Psychological Review 8/2: 145-157. Available at https://doi.org/10.1037/h0076100.

Duchowski, Andrew (2017). Eye Tracking Methodology. Theory and Practice. Berlin: Springer.

Frith, Chris (2007). Making up the Mind: How the Brain Creates Our Mental World. Oxford: Blackwell.

Godfroid, Aline (2019). Eye Tracking in Second Language Acquisition and Bilingualism: A Research Synthesis and Methodological Guide. New York: Routledge.

Grucza, Sambor (2011). "Lingwistyka antropocentryczna a badania okulograficzne" [Anthropocentric Linguistics and Eye-Tracking Research]. Lingwistyka Stosowana. Applied Linguistics. Angewandte Linguistik 4: 149-162. Available at www.ls.uw.edu.pl/ web/ lingwistyka-stosowana/ls4.

Grucza, Sambor (2013a). "Die Augen reden mächtiger als die Lippen. Eye-Tracking-'Einblicke' in die Sprache” [The Eyes Speak More Powerfully than the Lips. Eye-Tracking Insights into Language]. Zeitschrift des Verbandes Polnischer Germanisten. Czasopismo Stowarzyszenia Germanistów Polskich 2: 189-202. Available at www.ejournals.eu/ZVPG/Tom-2(2013)/Zeszyt_2_(2013)/art/2647/.

Grucza, Sambor (2013b). "Probleme? Nichts weiter als dornige Chancen: Zu Parametern und Maßeinheiten der Eye-Tracking-Translatorik" [Problems? Nothing more than thorny chances: The parameters and measures of the eye-tracking translation studies] Studia Translatorica 4: 11-22.

Grucza, Sambor (2014). "Grundzüge der anthropozentrischen Translatorik" [The Rudiments of Anthropocentric Translation Studies]. In: Łyp-Bielecka Aleksandra (ed.). Mehr als Worte. Sprach- 
wissenschaftliche Studien. Professor Dr. habil. Czesława Schatte und Professor Dr. habil. Christoph Schatte gewidmet. Katowice, 127-137.

Grucza, Sambor, Anna Bonek, Maria Castelas, Dominik Kudła, Monika Płużyczka, Mateusz Patera (2019). Czytanie pretranslacyjne a jakość tłumaczenia a vista $w$ świetle wyników badania okulograficznego. [Pre-translation reading and the quality of sight translation in the light of eye-tracking study results]. Warszawa: Wydawnictwo Naukowe IKSI. Available at [http://sn.iksi.uw.edu.pl/wpcontent/uploads/sites/306 /2019/09/SN-46-Grucza-et-al.-Czytanie-pretranslacyjne-a-tlumaczenie-a-vista.pdf].

Grucza, Sambor, Magdalena Olpińska-Szkiełko, Monika Płużyczka, Ilona Banasiak, Marcin Łączek, Anna Bonek, Agnieszka Kaleta, Alicja Sztuk (eds.) (2017a). Franciszek Grucza, Dzieła zebrane, t. 5: O uczeniu języków i glottodydaktyce antropocentrycznej I. Warszawa: Wydawnictwo Naukowe IKSI. Available at http://www.iksi. uw.edu.pl/documents/1173 8337/14640936/FG_Tom_5.pdf. Accessed 23.12.2019.

Grucza, Sambor, Magdalena Olpińska-Szkiełko, Monika Płużyczka, Ilona Banasiak, Marcin Łączek, Anna Bonek, Agnieszka Kaleta, Alicja Sztuk (eds.) (2017b). Franciszek Grucza, Dzieła zebrane, t. 8: Zagadnienia metalingwistyki. Lingwistyka - jej przedmiot, lingwistyka stosowana. Warszawa: Wydawnictwo Naukowe IKSI. Available at http:// www.iksi.uw.edu.pl/documents/11738337/ 14640936/FG_Tom_8.pdf. Accessed 23.12.2019.

Grucza, Sambor, Monika Płużyczka, Paweł Soluch (eds.). (2014). Widziane inaczej: $Z$ polskich badań eyetrackingowych. Warszawa: Wydawnictwo Naukowe IKSI. Available at http://sn.iksi.uw.edu. pl/wp-content/ uploads/sites/306/2018/ 08/SN-41-A.-Andrychowicz-Trojanowska-Podr \%C4 \%99czn iki-glottodydaktyczne.pdf.

Hajduk, Zygmunt (1996). „Sposoby uzasadniania teorii metodologicznych". Filozofia Nauki 4/3: 87-94.

Hansen-Schirra, Silvia, Sambor Grucza (eds.) (2016). Eye Tracking and Applied Linguistics. Berlin: Language Science Press. Available at http:/ / langsci-press.org/catalog/book/ 108.

Holmqvist, Kenneth, Richard Andersson (2017). Eye Tracking: A Comprehensive Guide to Methods, Paradigms and Measures. Lund: Lund Eye-Tracking Research Institute. 
Huey, Edmund B. (1898). "Preliminary experiments in the physiology and psychology of reading". The American Journal of Psychology 9(4): 575-886. Available at https://doi: 10.2307/1412192.

Luria, Alexander R. (1974), "Language and brain towards the basic problems of neurolinguistics". Brain and Language 1: 1-14.

Ober, J. K., J. J. Ober (2000a). „Pomiar ruchu oka metoda bezpośredniej podczerwieni cz. I". Technika Sensorowa Elektronizacji 2: 2428.

Ober, J. K., J. J. Ober (2000b). "Pomiar ruchu oka metoda bezpośredniej podczerwieni cz. II". Technika Sensorowa Elektronizacji 3: $21-24$.

Ober, J. K., J. J. Ober, M. Malawski, M. Skibniewski, Elżbieta Przedpelska-Ober, J. Hryniewiecki (2002). „Monitoring pilot's eye movements during the combat flight - the white box". Biocybernetics and Biomedical Engineering 22/2-3: 241-264.

Ober, J. K., J. Dylak, W. Gryncewicz, Elżbieta Przedpelska-Ober (2009). „Sakadometria - nowe możliwości oceny stanu czynnościowego ośrodkowego układu nerwowego" [Sacadometry - new possibilities of assessing the functional state of the central nervous system]. Nauka 4: 109-135.

Płużyczka, Monika (2015). Tłumaczenie a vista. Rozważania teoretyczne $i$ badania eyetrackingowe [Sight translation. Theoretical Considerations and Eye Tracking Experiments]. Wydawnictwo Naukowe IKSI. Available at http://sn.iksi.uw.edu.pl/wpcontent/uploads/sites/306/2018/09/SN-30-Monika-P\%C5 \%82 u\%C5\%BCyczka-T\%C5\%82umaczenie-a-vista.-Rozwa\%C5\%BCania-teoretyczne-i-badania-eyetrackingowe.pdf.

Poole, Alex, Linden J. Ball (2006). "Eye Tracking in Human-Computer Interaction and Usability Research: Current Status and Future Prospects". In: Claude Ghaoui (ed.). Encyclopedia of Human-Computer Interaction. Idea Group, Inc., PA, USA.

Richardson, Daniel C., Michael J. Spivey (2004). "Part 1: Eye-tracking: characteristics and methods; Part 2: Eye-tracking: research areas and applications". In: Gary E. Wnek, Gary L. Bowlin (eds.). Encyclopedia of Biomaterials and Biomedical Engineering. Available at www.eyethink.org/publications_assets/ EyeTrackingEBBE.pdf.

Sandra, Dominiek (1998) "What linguists can and can't tell you about the human mind: A reply to Croft". Cognitive Linguistics 9/4:361378. 
Soluch, Paweł, Adam Tarnowski (2013). "Eye-tracking methods and measures". In: Sambor Grucza, Monika Płużyczka, Justyna Zając (eds.) (2013). Translation Studies and Eye-Tracking Analysis. Frankfurt am Main: Peter Lang Verlag, 85-104.

Spinner, Patti, Susan M. Gass, Jennifer Behney (2013). "Ecological validity in eye-tracking: An empirical study". Studies in Second Language Acquisition 35/2: 389-415. Special Issue: "Eye-Movement Recordings in Second Language Research".

Wade, Nicholas J. (2010). "Pioneers of eye movement research". i-Perception 1/2: 33-68. Available at https://doi.org/ 10.1068/i0389.

\author{
Sambor Grucza \\ ORCID iD: 0000-0001-7801-8444 \\ University of Warsaw \\ Instytut Komunikacji Specjalistycznej \\ i Interkulturowej \\ ul. Szturmowa 4 \\ 02-678 Warszawa \\ Poland \\ sambor.grucza@uw.edu.pl
}

